22 Melton LJ. Epidemiology of fractures. In: Riggs BL, Melton LJ, eds. Osteoporosis: etiology, diagnosis and management. New York: Raven Press, 1988:133-54.

23 Grisso JA, Chiu GY, Maislin G, Steinmann WC, Portable J. Risk factors for hip fractures in men: a preliminary study. $\mathcal{J}$ Bone Miner Res 1991;8:865-8.

24 Simons LA, McCallum J, Simons J, Powell I, Ruys J, Heller R, et al. The Dubbo study: an Australian prospective community study of the health of the elderly. Aust N Z F Med 1990;20:783-9.

25 Angus RM, Sambrook PN, Pocock NA, Eisman JA. A simple method for assessing calcium intake in Caucasian women. 7 Am Diet Assoc 1989;89: 209-14.

26 Semmes J, Weinstein S, Ghent L. Somatosensory changes after penetrating brain wounds in man. Cambridge, Massachusetts: Harvard University Press, 1960

7 Dichgans J, Held R, Young LR, Brandt T. Moving visual scenes influence the apparent direction of gravity. Science 1972;178:1217-9.

28 Lord SR, Clarke RD, Webster IW. Postural stability and associated physiological factors in a population of aged persons. I Gerontol 1991;46:M57-66. Cox DR, Snell EJ. The analysis of binary data. 2nd ed. London: Chapman \& Hall, 1989.

Hall, 1989 .
30 Harrell FE, Califf RM, Pryor DB, Rosati RA. Evaluating the yield of medical Harrell FE, Califf RM, Pryor DB,
tests. $f A M A$ 1982;247:2543-6.

31 Hanley JA, MCNeil BJ. The meaning and use of the area under a receiving operating characteristic (ROC) curve. Radiology 1982;50:23-36.
32 Hand DJ. Discrimination and classification. New York: Wiley, 1982.

33 SAS Institute. SAS/STAT: user's guides. Cary, North Carolina: SAS Institute, 1990

34 Cooper C, Aitkinson EJ, O'Fallon WM, Melton LJ. Incidence of clinically diagnosed vertebral fractures: a population based study in Rochester, Minnesota, 1985-1989. F Bone Miner Res 1992;7:221-7.

35 Cummings SR, Black DM, Nevitt MC, Browner W, Cauley J, Ensrud K, et al. Bone density at various sites for prediction of hip fractures. Lancet 1993;341:72-5.

36 Brocklehurst JC, Robertson D, James-Groom P. Clinical correlates of sway in old age-sensory modalities. Age Ageing 1982;11:1-10.

37 Fernies GR, Gryfe CI, Holliday PJ, Lewellyn A. The relationship of postural sway in standing to the incidence of falls in geriatric subjects. Age Ageing 1982;11:11-6.

38 Lord SR, McLean D, Stathers G. Physiological factors associated with injurious falls in older people living in the community. Gerontolog 1992;38:338-46.

39 Hui SL, Slemenda CW, Johnton CC. Age and bone mass as predictors of fracture in prospective studies. $\mathcal{F}$ Clin Invest 1987;81:1804-9.

40 Cummings SR, Nevitt MC. A hypothesis: the causes of hip fractures $f$ Gerontol 1989;44:M107-11.

(Accepted 23 August 1993)

\title{
Influence of social deprivation on illness in diabetic patients
}

\author{
William F Kelly, Rashad Mahmood, \\ Miranda J Kelly, Steve Turner, Keith Elliott
}

Diabetes Care Centre, Middlesbrough General Hospital, Middlesbrough TS5 5AZ

William F Kelly, consultant physician

Miranda J Kelly, diabetes

liaison sister

School of Computing and Mathematics, University of Teesside,

Middlesbrough TS1 3BA

Rashad Mahmood, student

Cleveland County Council

Research and Intelligence

Unit, Middlesbrough

TS1 2YW

Steve Turner, chief

statistician

Keith Elliott, research officer

Correspondence to:

Dr Kelly.

BMF 1993;307:1115-6
Inequalities in health are associated with social deprivation..$^{1-3}$ Our hospital serves a district of 286000 people with considerable differences in environmental and social circumstances. We therefore investigated whether illness in diabetic patients is linked to deprivation by analysing data on diabetic patients from contrasting socioeconomic backgrounds.

\section{Patients, methods, and results}

A standardised form for the diabetic register has been completed for all patients visiting this centre since 1984, and the results have been computerised since 1987. For this study we analysed demographic details and details of diabetic complications and treatment. The electoral wards where patients lived were determined from postal codes. The prosperity of wards was ranked using data on unemployment, no car ownership, overcrowding, the proportion of rented accommodation, and the proportion of households of socioeconomic classes 4 and $5 .^{2}$ Parametric and non-parametric statistics were used to compare patients from the most and least deprived wards; significance was taken as $\mathrm{p}<0.05$.

Of 1528 patients seen in 1991, 241 lived in the eight most deprived wards, 247 in the 10 least deprived wards, and 1040 in the remaining intermediate wards. Overall, 886 were men, 371 smoked, and only 81 were from ethnic minority groups; 161 were treated by diet alone, 586 with oral drugs, and 748 with insulin, with 33 not recorded.

The table shows that patients from the deprived inner city were significantly older with a shorter duration of diabetes than those from the properous wards. Insulin was used significantly less frequently in the inner city, where smoking was more common. Ischaemic heart disease and peripheral vascular disease were significantly more prevalent in the inner city. When smokers were analysed separately, ischaemic heart disease was no longer significantly associated with living in the inner city $(p=0.57$, odds ratio 1.3$)$; however, for non-smokers the association between ischaemic heart disease and living in the inner city remained significant $(p=0.0003$, odds ratio 2.81 (95\% confidence interval 1.51 to $5 \cdot 25)$ ). Proportionally more people from our district lived alone in the inner city than lived alone in the prosperous wards $(31 \% v 25 \%$ respectively).

\section{Comment}

Diabetic patients from the socially and economically deprived inner city were less likely to use insulin, and more likely to smoke and to have cardiovascular disease than were patients from the prosperous wards. Smoking ranged from $32 \%$ in the deprived inner city, to $25 \%$ in the intermediate area, to $19 \%$ in the prosperous wards. This increased prevalence of smoking among inner city residents has been noted previously ${ }^{4}$ and partly explains their high prevalence of ischaemic heart disease. Smoking is recorded at each visit to our clinic and advice is repeated to reduce and eventually stop smoking. The overall prevalence of smoking in our clinic has fallen from $26 \%$ in 1987 to $22 \%$ in 1992 .

Inner city residents are more likely to be older and living alone. They may therefore be reluctant to use insulin.

Previous reports have commented on the associations between poor housing, unemployment and poverty, and general health problems, including an increased risk of respiratory and cardiac disease and a decreased

Data on diabetic patients according to prosperity of electoral ward where they lived

\begin{tabular}{|c|c|c|c|c|c|}
\hline & \multicolumn{3}{|c|}{ Prosperity of ward } & \multirow[b]{2}{*}{$\begin{array}{c}\text { Odds ratio } \\
(95 \% \text { confidence interval })^{\star}\end{array}$} & \multirow[b]{2}{*}{ p Value } \\
\hline & $\begin{array}{l}\text { Deprived } \\
(n=241)\end{array}$ & $\begin{array}{l}\text { Intermediate } \\
(\mathrm{n}=1040)\end{array}$ & $\begin{array}{l}\text { Prosperous } \\
(\mathrm{n}=247)\end{array}$ & & \\
\hline Median age (range) (years) & $58(14-83)$ & $57(9-89)$ & $54(9-84)$ & & $0.018 t$ \\
\hline Median duration of diabetes (range) (years) & $6(1-51)$ & $8(1-59)$ & $9(1-43)$ & & $0.005 t$ \\
\hline \multicolumn{6}{|l|}{ Proportion $(\%)$ of patients: } \\
\hline Taking insulin & $101 / 234(43)$ & $506 / 1020(50)$ & $141 / 241(59)$ & $0.54(0.37$ to 0.79$)$ & $0.0008 \ddagger$ \\
\hline Who smoked & $75 / 236(32)$ & $251 / 1005(25)$ & $45 / 238(19)$ & $2.00(1.27$ to 3.14$)$ & $0.0013 \ddagger$ \\
\hline With ischaemic heart disease & $57 / 231(25)$ & $175 / 989(18)$ & $29 / 237(12)$ & $2.35(1.39$ to 3.97$)$ & $0.0005 \ddagger$ \\
\hline With peripheral vascular disease & $47 / 224(21)$ & $136 / 941(14)$ & $30 / 225(13)$ & $1.73(1.01$ to 2.95$)$ & $0.043 \ddagger$ \\
\hline
\end{tabular}

^Comparing patients from deprived wards with those from prosperous wards.

tKruskal-Wallis test.

$\ddagger \chi^{2}$ test. 
life expectancy. ${ }^{1-3}$ Some reports have included data from north east England. ${ }^{5}$ To our knowledge, however, no previous reports have assessed illness in diabetic patients in relation to social deprivation.

In conclusion, we advocate three courses of action: firstly, to support the alleviation of social and economic disadvantage; secondly, to offer an excellent service to our patients with diabetes, aiming at optimal glycaemic control in order to minimise the risk of complications; and, thirdly, to continue to persuade patients not to smoke.

We thank Middlesbrough Inner City Funding for a grant,
Elaine Scott for maintaining our computer database, and Kay McGowan for secretarial help.

1 Black D, Morris NN, Smith C, Townsend P. Report of the working group on inequalities in health. London: Department of Health and Social Security, 1980

2 Townsend P, Phillimore P, Beattie A. Health and deprivation-inequality and the North. London: Routledge, 1988.

3 Townsend $\mathrm{P}, \mathrm{Davidson} \mathrm{N}$, Whitehead M, eds. Inequalities in health. The Black report and the health divide. London: Penguin, 1992.

4 Marsh GN, Channing DM. Deprivation and health in one general practice. $B M \mp 1$ 1986;292:1173-6.

5 Phillimore PR, Morris D. Discrepant legacies: premature mortality in two industrial towns. Soc Sci Med 1991;33:139-52.

(Accepted 5 fuly 1993)

\section{Childless women revisited}

\section{Gina Johnson for the South Bedfordshire Practitioners' Group}

Members of the South Bedfordshire Practitioners' Group are listed at the end of the article.

Wigmore Lane Health Centre, Luton LU2 8BG Gina Johnson, general practitioner

BMF 1993;307:1116-7
In 1985 we examined the general practice records of a group of women born in 1935 and 1950 to determine the prevalence of childlessness-both voluntary and due to infertility. ${ }^{1}$ We reassessed the same variables seven years later in women born in 1950 .

\section{Subjects, methods, and results}

In 1992 we identified all women born in 1950 from our nine practices with a combined list of 76100 patients. In each record we noted (a) consultations about infertility or subfertility; $(b)$ whether at least one living child had been born; $(c)$ evidence of voluntary childlessness-that is, current contraceptive usage, sterilisation of the woman or her partner, termination of pregnancy, or a written comment in the notes-and (d) whether she had been included in our previous study.

The childless women were divided into three groups: infertile, voluntarily childless, or unclassified. Using the $\chi^{2}$ test, we compared the results with those for the women born in 1950 in our previous study.

We identified 474 women born in 1950 , of whom 459 had complete records. Of these, $24(5 \cdot 2 \%)$ had consulted a doctor about infertility; five of them remained childless and were classified as infertile $(1 \cdot 1 \%)$. In total, 55 women $(12 \%)$ had not had a live birth; 34 of them $(7 \cdot 4 \%)$ were classified as voluntarily childless.

There remained 16 unclassified women $(3 \cdot 5 \%)$. This group might contain, in any proportions, celibate women, women using non-prescribed contraception, and women who had been unsuccessful in conceiving but had not sought medical help. Assuming that the ratio of infertility to voluntary childlessness was the same in the unclassified and classified groups, the prevalences of $7 \cdot 4 \%$ and $1 \cdot 1 \%$ were multiplied by $55 / 39$, giving estimates of $10.5 \%$ (48) for voluntary childlessness and $1.6 \%$ (seven) for infertility. With the same assumption, voluntary childlessness was estimated as $11.0 \%(68 / 617)$ and infertility 3.2\% (20/617) in 1985 (95\% confidence interval for comparison between studies $7 \cdot 0 \%$ to $15 \cdot 7 \%$ and $1 \cdot 1 \%$ to $6 \cdot 1 \%$ respectively; not significant).

There was no significant difference in any other variable between the two studies (proportion who saw a specialist about infertility $6.8 \%(42)$ in $1985 v 5.2 \%$ (24) in $1985(3.7 \%$ to $10.7 \%)$; proportion who were childless $14.3 \%$ (88) $v 12.0 \%$ (55) $(9 \cdot 8 \%$ to $19 \cdot 4 \%)$; proportion who were voluntarily childless $9 \cdot 2 \%(57) v$ $7 \cdot 4 \%$ (34) $(5 \cdot 7 \%$ to $13.5 \%)$; proportion who were infertile $2 \cdot 8 \%$ (17) $v 1 \cdot 1 \%$ (five) $(0.9 \%$ to $5 \cdot 4 \%$ ); and proportion who were unclassified $2.3 \%$ (14) $v 3.5 \%$ (16) $(0 \cdot 7 \%$ to $4 \cdot 8 \%))$.

Twenty seven women were identified as childless in 1985; three of them had since had a child. None of those whom we had classified as voluntarily childless in 1985 had subsequently borne a living child; there was no evidence that they were merely delaying childbearing, except for one woman with a family history of Huntington's chorea who subsequently discovered that she was infertile.

\section{Comment}

Our second study confirms that many women born in 1950 are choosing to remain childless; unresolved primary infertility is uncommon.

A group in Oxford recently estimated that $3.4 \%$ of 683 women aged 25 to 44 had primary unresolved infertility. ${ }^{2}$ This figure is probably too high as their subjects included many young women who might subsequently conceive. A study of 83 childless menopausal women in Aberdeen concluded that 3.5\% had primary unresolved infertility and $7 \%$ were voluntarily childless. ${ }^{3}$ Our previous results suggest that women from this older generation are less likely to be childless by choice; also they did not have access to modern treatments for infertility.

Childlessness is increasing. Using statistics from the Office of Population Censuses and Surveys Jones estimated that of all women in England and Wales who were born in $1950,42 \%$ were childless at 25 and $15 \%$ at 40 (figure).$^{4}$ Of those born in $1965,60 \%$ were childless at 25 . How many of these women will remain so? The answer has important implications for British society.

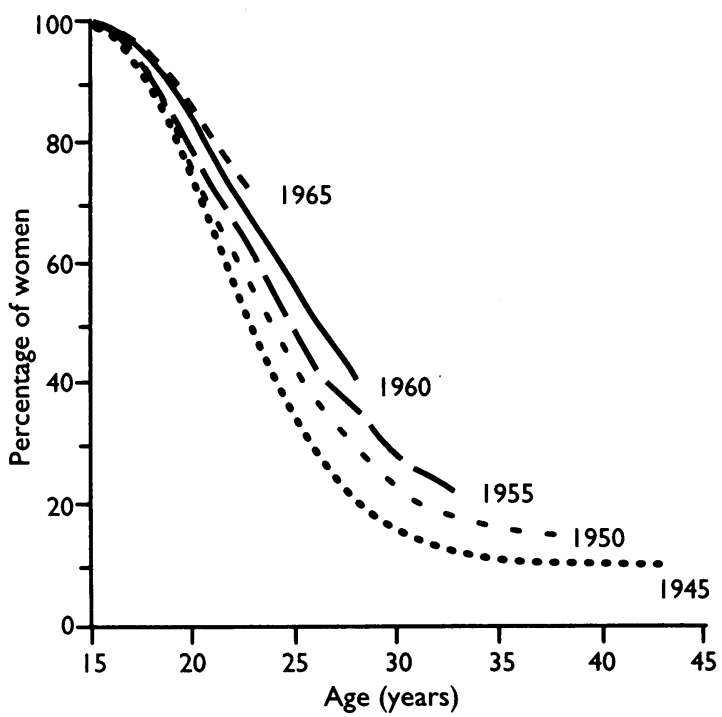

Percentages of women born in 1945, 1950,1955, 1960, and 1965 who were childless at successive ages (England and Wales). ${ }^{4}$ Reproduced with permission 